\title{
ТЕОРЕТИЧНІ ОСНОВИ ДОСЛІДЖЕННЯ ДЕРЖАВНИХ ФІНАНСІВ В СИСТЕМІ СОЦАЛЬНОГО ЗАХИСТУ НАСЕЛЕННЯ
}

\author{
ДВНЗ "Прикарпатський національний університет імені \\ Василя Стефаника", \\ Міністерство освіти і науки України, \\ кафедра фінансів, \\ вул. Шевченка, 57, м. Івано-Франківськ, \\ 76018 , Україна, \\ tel.: (0342) 59-61-76, 75-23-91, \\ e-mail: ilonaborushok@i.ua
}

\begin{abstract}
Анотація. У статті проведено дослідження та узагальнення теоретичних підходів щодо фінансового забезпечення соціального захисту населення у взаємозв'язку 3 фінансовим державним потенціалом та визначено його вплив на соціально-економічний розвиток України.

Запропоновано авторське визначення сутності державних фінансів та соціального захисту, як процесу, що забезпечує незахищеним верствам суспільства однакові фінансові можливості через справедливий розподіл фінансових ресурсів та відповідальність держави. Запропоновано заходи покращення соціального захисту при залученні фінансового потенціалу держави.

Проведено аналіз сучасної системи соціального захисту населення, визначено невідповідність обсягів функцій держави та обсягів фінансових ресурсів і окреслено шляхи усунення цих диспропорцій.

Ключові слова: державні фінанси, соціальний захист, соціальне забезпечення, соціальна сфера, фінансовий потенціал держави, фінансові ресурси, функції державних фінансів, фінансовий механізм.
\end{abstract}

\section{Borushok I. THEORETICAL BASIS OF STATE FINANCE RECEARCH IN THE SYSTEM OF SOCIAL PROTECTION}

\author{
Vasyl Stefanyk Precarpathian National University, \\ Ministry of Education and Science of Ukraine, \\ Department of Finance, \\ Shevchenko str., 82, Ivano-Frankivsk, \\ 76018, Ukraine, \\ tel.: (0342) 59-61-76, 75-23-91, \\ e-mail: ilonaborushok@i.ua
}

\begin{abstract}
An important function of public finances is the creation of favorable conditions for the development of the domestic economy, raising the social standards of citizens and their social protection. Effective use of public finances helps to solve the problem of sustainable economic and social development of the state. The volatile external economic environment in the country, the crisis in the economy require in-depth study of the social protection system in the context of the public finances. The search of new mechanisms of the formation and management of public finances will ensure the dynamic development of Ukrainian economy, and its balance and rational use will lead to the formation of a favorable macroeconomic situation, which will contribute to the effective development of entrepreneurship, investment growth, as well as stability in the social protection and social security system. The theoretical approaches to financial support for social protection of the population in relation to the financial state potential and its impact on the socio-economic
\end{abstract}


108 Борушок I.I. Теоретичні основи...

development of Ukraine are generalized.The author defines the essence of the state finances and social protection as a process that provides the unprotected sections of society with equal financial opportunities through fair distribution of financial resources and responsibility of the state. Measures to improve social protection while attracting the financial potential of the state are proposed.The analysis of the modern system of social protection of the population is conducted, the discrepancy between the volume of functions of the state and the volume of financial resources is determined, and the ways of eliminating these disparities are outlined.

Keywords: public finances, social protection, social security, social sphere, financial potential of the state, financial resources, functions of public finances, financial mechanism.

Вступ. Важливою функцією державних фінансів $є$ формування сприятливих умов для розвитку вітчизняної економіки, підвищення соціальних стандартів громадян та їх соціального захисту. Ефективне використання державних фінансів забезпечує розв'язання проблеми сталого економічного та соціального розвитку держави.

Постановка завдання. Нестабільне зовнішнє економічне середовище в країні, кризові явища в економіці, все це зумовлює необхідність поглибленого дослідження системи соціального захисту у рамках державних фінансів.

Пошук нових механізмів формування та управління державними фінансами забезпечить динамічний розвиток економіки України, а збалансованість та раціональне їх використання зумовить формування сприятливої макроекономічної ситуації, що сприятиме ефективному розвитку підприємництва, зростанню інвестицій, а також стабільності в системі соціального захисту та соціального забезпечення.

Результати. Сучасна система державних фінансів відіграє чи не найважливішу роль у фінансовій системі країни. Важливість державних фінансів випливає з функцій державних фінансів, які полягають у забезпеченні сталого економічного розвитку держави, забезпеченні виконання державою своїх соціально-економічних функцій, забезпеченні держави необхідними фінансовими ресурсами для виконання покладених на неї завдань.

Вагомий внесок у дослідження теорії державних фінансів та їх ролі у фінансовій системі країни здійснили такі відомі вчені, як А. Вагнер, Ф. Нітті, П. Самуельсон, Дж. М. Кейнс. Серед вітчизняних дослідників можемо виділити вчення І. Г. Ткачук, В. Базилевича, В. М. Опаріна, А. Г. Загороднюк та Г. Л. Возняка.

Опираючись на твердження вітчизняних науковців система державних фінансів $€$ центральною ланкою у фінансовій системі держави, адже забезпечує необхідними фінансовими ресурсами галузі та сфери державного сектору економіки, з її допомогою посилюється вплив держави на соціальний та економічний розвиток країни, а в результаті, забезпечується ефективне виконання державою покладених на них функцій та завдань $[1,2,3]$.

Роль державних фінансів у системі соціального захисту та їх вплив на формуванні цієї системи розглянемо через визначення соціального захисту.

Поняття "соціальний захист" в Україні закріплене конституційно. В статті 21 Конституції України вказано, що людина, іiі життя і здоров'я - це найвища цінність держави, а забезпечення прав і свобод громадянина $\epsilon$ найбільшим пріоритетом держави [4]. Відповідно до Конституції ознаками України, як соціальної держави, є соціальна спрямованість економіки, закріплення соціальних гарантій реалізації соціальних прав громадян, зокрема прав на соціальний захист та належний рівень життя. Відповідно до цих ознак, держава зобов'язана:

1. Гарантувати кожному громадянинові достатній рівень та умови життя, в частині встановлення належного рівня мінімальної заробітної плати та їі індексації відповідно до прожиткового мінімуму, помірних податків, надання можливості розвитку підприємництва через невтручання держави у їх діяльність; 
2. Гарантувати на законодавчому рівні громадянам право на працю, соціальний захист населення, освіту, охорону здоров'я, культуру тощо;

3. Застосовувати та регулювати справедливі та ефективні форми перерозподілу суспільного доходу задля забезпечення добробуту громадян;

4. Максимально вирівнювати рівень добробуту найбільш вразливих верств населення, соціальна забезпеченість яких є недостатньою у зв'язку з причинами, які не залежать від їхніх трудових зусиль.

Отже, основні зобов'язання соціальної держави, полягають у задоволенні найбільш пріоритетних потреб суспільства, які окремий громадянин не в змозі забезпечити самостійно.

Розглянемо детальніше теоретичні підходи вітчизняних авторів щодо інтерпретації концепту “соціальний захист населення" та спробуємо провести їх контент-аналіз (табл.1). Кожен 3 вищенаведених науковців розглядав дефініцію “соціальний захист" виходячи 3 діючої на той час системи соціального захисту населення. Хоча, кожен науковець трактував дане поняття по різному, все ж спільним в них $є$ те, що необхідний обсяг соціальних гарантій населенню повинен надаватися виключно державою. Так, автор підручника “Державні фінанси” I. Г. Ткачук детально описує соціальні гарантії держави, які полягають у створенні умов самозабезпечення громадян життєво необхідними благами для задоволення власних потреб; вилучаючи в громадян частину створеного ними валового внутрішнього продукту, держава повертає їм блага та послуги у формі освіти, дошкільного виховання, охорони здоров'я, соціального страхування тощо. Тобто, соціальний захист включає заходи, які повинні бути гарантіями кожному громадянинові на певний рівень благ і послуг за рахунок власних соціальних внесків і розподілу ресурсів між населенням на цілі їхнього матеріального забезпечення [9, с. 320]. Отже, виходячи з вищевикладеного можемо запропонувати визначення соціального захисту, під яким розуміємо складний процес, що забезпечує незахищеним верствам суспільства однакові фінансові можливості через справедливий перерозподіл фінансових ресурсів, відповідальність держави за допомогою фінансового потенціалу.

Держава використовує державні фінанси як важіль впливу на соціальне становище та соціальний захист населення. Негативними наслідками такого впливу $є$ надмірна централізація державних фінансів, внаслідок чого немає ефективного розподілу фінансових ресурсів. На нашу думку, досягнення позитивних змін можливе за рахунок оптимізації структури видатків бюджету.

Значна увага приділяється стратегії економічного розвитку країни, а одне 3 пріоритетних місць в цій стратегії належить фінансовому потенціалу країни. Питання фінансового потенціалу є важливим у контексті проблематики нашого дослідження, оскільки саме від нього залежить ефективність фінансового забезпечення соціального захисту.

Як фінансова категорія, фінансовий потенціал відображає соціально-економічні відносини, що виникають у процесі фінансово-господарської діяльності суб'єктів господарювання з приводу формування, розподілу та перерозподілу, використання та примноження його фінансових активів, які впливають на фінансову стійкість держави [11, с. 118-126].

Відповідно до Закону України “Про соціальні послуги”, фінансове забезпечення соціальних програм здійснюється за рахунок коштів Державного та місцевих бюджетів, спеціальних фондів, коштів підприємств, установ, організацій благодійної допомоги та інших джерел, передбачених в законі [12].

Враховуючи рівень фінансування соціального захисту населення в Україні протягом 2015-2018 рр., можемо зробити висновок, що наша держава відстає від 
більшості розвинених країн, що вимагає пошуку альтернативних шляхів підвищення фінансування соціальної сфери, а отже, ефективного використання державних фінансів.

\section{Визначення концепту “соціальний захист” вітчизняних авторів}

Таблиия 1

Table 1

Definition of the concept of "social protection" of domestic authors

\begin{tabular}{|c|c|}
\hline Автори & Визначення поняття “соціальний захист” \\
\hline \multicolumn{2}{|r|}{ Як форма фінансової підтримки громадян } \\
\hline $\begin{array}{c}\text { Дідківська Л. І., } \\
\text { Головко Л. С. }\end{array}$ & $\begin{array}{l}\text { “Соціальний захист населення - державна підтримка } \\
\text { певних категорій населення, які можуть зазнавати } \\
\text { негативного впливу ринкових процесів, забезпечення } \\
\text { відповідного рівня життя шляхом надання правової, } \\
\text { фінансової, матеріальної допомоги окремим громадянам } \\
\text { (найбільш вразливим верствам населення), а також } \\
\text { створення соціальних гарантій для економічно активної } \\
\text { частини населення, забезпечення прийнятних для країни } \\
\text { умов життя та праці громадян, у тому числі через } \\
\text { установлення соціальних стандартів” [5] }\end{array}$ \\
\hline Москаленко В. В. & $\begin{array}{l}\text { “Соціальний захист - це певний механізм, за } \\
\text { допомогою якого досягається мінімальний життєвий рівень } \\
\text { громадян, це система заходів і відповідних інститутів, } \\
\text { призначених для забезпечення нормального існування } \\
\text { людини, підвищення рівня задоволення пї соціальних потреб, } \\
\text { якості життя та перспектив” [6] }\end{array}$ \\
\hline \multicolumn{2}{|c|}{ Як сукупність заходів, спрямованих на збереження соціального добробуту } \\
\hline $\begin{array}{c}\text { Скуратівський В., } \\
\text { Палій О., Лібанова Е. }\end{array}$ & $\begin{array}{l}\text { “Соціальний захист - це комплекс організаційно- } \\
\text { правових та економічних заходів, спрямованих на захист } \\
\text { добробуту кожного члена суспільства в конкретних } \\
\text { економічних умовах" [7] }\end{array}$ \\
\hline Шевчук П. І. & $\begin{array}{l}\text { “Соціальний захист - це комплекс організаційно- } \\
\text { правових та економічних заходів, спрямованих на } \\
\text { забезпечення життя, здоров'я та добробуту населення за } \\
\text { конкретних економічних умов” [8] }\end{array}$ \\
\hline \multicolumn{2}{|c|}{ Як вид діяльності держави у сфері соціальної політики } \\
\hline Ткачук I. Г. & $\begin{array}{l}\text { “Соціальний захист являє собою заходи (методи) } \\
\text { забезпечення } 3 \text { боку держави задоволення різноманітних } \\
\text { потреб громадян на рівні соціально визнаних норм" [9] }\end{array}$ \\
\hline Болотіна Н. & $\begin{array}{l}\text { "Поняття “соціальний захист” у широкому розумінні } \\
\text { визначають як діяльність держави, спрямовану на } \\
\text { забезпечення формування й розвитку повноцінної } \\
\text { особистості, виявлення й нейтралізацію негативних } \\
\text { факторів, що впливають на неї, створення умов для } \\
\text { самовизначення і ствердження ужитті. У вузькому розумінні } \\
\text { соціальний захист визначають як сукупність економічних і } \\
\text { правових гарантій, що забезпечують додержання } \\
\text { найважливіших соціальних прав громадян, досягнення } \\
\text { соціально прийнятного рівня життя" [10] }\end{array}$ \\
\hline
\end{tabular}

Джерело: складено автором на основі [5; 6; 7; 8; 9; 10] 
Основними завданнями, спрямованих на забезпечення фінансування соціальної сфери через залучення фінансового державного потенціалу, на нашу думку, $є$ :

- аналіз достатності обсягів фінансових ресурсів,

- збалансованість потреб та можливостей забезпечення фінансовими ресурсами,

- обгрунтованість побудови фінансових потоків та оцінка їх результативності, впровадженні інновацій [13, с. 78-79].

Забезпечення виконання даних завдань можливе за рахунок фінансового механізму, що являє собою розробку системи формування фінансових потоків бюджетів різних рівнів, а також ефективне ії впровадження.

На теперішньому етапі розвитку соціальної сфери в Україні, існує диспропорція між обсягами функцій держави щодо соціального захисту та обсягами фінансових ресурсів, необхідних для їх впровадження, а, отже, спостерігається недофінсування соціальної сфери [13, с. 172-179]. Це є головним завданням фінансової політики держави у забезпеченні соціального захисту населення і потребує випрацювання нових ефективних механізмів їі реалізації.

Висновки. Отже, ключовий аспект соціально-економічного розвитку держави відведено створенню належних умов для розвитку економіки, забезпеченню сприятливого рівня надання соціальних послуг, підвищенню рівня якості та життя громадян. Досягти поставлених завдань можливо виключно за рахунок якісного, ефективного та економного функціонування механізму державних фінансів, під яким ми розуміємо сукупність організаційно-правових та економічних форм, методів управління фінансовими ресурсами, через який держава здійснює вплив на розвиток економіки, забезпечує надання соціальних гарантій населенню України.

В Україні функціонування механізму державних фінансів в сфері соціального захисту має першочергове значення для життя суспільства. Виступаючи основним індикатором впливу на соціально-економічний розвиток суспільства, державні фінанси формують основу економічної безпеки країни, оскільки через них держава забезпечує права, свободи та добробут громадян.

1. Карлін М. І. Фінансова система України: навчальний посібник для студ. вузів. К.: Знання, 2007. $324 \mathrm{c}$.

2. Шушкова Ю. В. Державні фінанси України та їх місце у фінансовій системі України. Економіка, планування та управління в галузях. Науковий вісник НЛТУ України. 2012. Вип. 22. 14. С. 345-350.

3. Загородній А. Г., Вознюк Г. Л., Смовженко Т. С. Фінансовий словник. Вид. 4-те, [перероб. та доп. ]. К.: Т-во «Знання», КОО; Львів: Вид-во ЛБІ НБУ, 2002. 566 с.

4. Конституція України. Закон України “Про внесення змін до Конституції України” № 2222-IV від 8.12.2004 р. : прийнята на п’ятій сесії Верхов. Ради України 28 черв. 1996 р. Київ : Велес, 2005. $48 \mathrm{c.}$

5. Дідківська Л. І., Головко Л.С. Державне регулювання економіки : навч. посіб. К. : Знання-Прес, 2000. 209 c.

6. Москаленко В. В. Сутність соціального захисту та його місце в політиці соціальної держави. Наукові записки. 2003. Том 21. С. 42.

7. Скуратівський В., Палій О. Соціальна політика. К. : Вид-во УАДУ, 2003. 265 с.

8. Шевчук П. І. Соціальна політика та соціальна безпека. Львів : Вид-во ЛРІДУ УАДУ, 2003. 178 с.

9. Ткачук I. Г. Державні фінанси : підручник. Івано-Франківськ : Прикарпат. нац. ун-т ім. В. Стефаника. 2015. 510 c.

10. Болотіна Н. Право людини на соціальне забезпечення в Україні: проблема термінів і понять / Н. Болотіна. Право України. 2000. № 4. С. 36.

11. Корієнко О. В. Проблеми бюджетного фінансування соціальної сфери та шляхи вирішення. Економічний простір. 2011. Вип. 46. С. 172-179.

12. Журавський В. С. та ін. Українські Закони. Соціальний кодекс України. К. : Логос, 1998. 319 с.

13. Бюджетний моніторинг : аналіз виконання бюджету за 2017 рік. URL: https:// www.ibser.org.ua 
112 Романчукевич В.В. Економічні напрями модернізації...

(дата звернення: 18.10.2019).

\title{
References
}

1. Carlin, M. Financial system of Ukraine: a textbook for student's Universities, Znannia, 2007.

2. Shushkova, Yu. "Public finances of Ukraine and their place in the financial system of Ukraine." Economics, planning and management in the branches, Scientific Bulletin of NLTU of Ukraine, no. 22 (14), 2012, pp. 345-350.

3. Zagorodnii, A. Financial Dictionary, Znannia, 2002.

4. The Constitution of Ukraine. Law of Ukraine "On Amendments to the Constitution of Ukraine, Veles, 2005.

5. Didkivska, L., and L. Golovlo State regulation of economy, Znannia-Press, 2000.

6. Moskalenko, V. "The essence of social protection and its place in the politics of the social state." Scientific notes, vol. 21, 2003.

7. Skurativsky V., and O. Paliy Social policy, UADU, 2003.

8. Shevchuk P. Social policy and social security, LRIDU UADU, 2003.

9. Tkachuk I. State finances, V. Stefanyk Precarpathian National University, 2015.

10. Bolotina, N. "Human right to social security in Ukraine: the problem of terms and concepts." Law of Ukraine, no. 4, 2000, p. 36.

11. Korienko, O. V. "Problems of budget financing of social sphere and ways of solution." Economic space, no. 46, 2011, pp. 172-179.

12. Zhuravsky, V. S. and others. Ukrainian Laws. Social Code of Ukraine, Logos, 1998.

13. Budget Monitoring. Analysis of Budget Execution 2017. USAID, www.ibser.org.ua. Accessed 18 Oct. 2019.

УДК 336.02

doi: 10.15330/apred.2.15.112-118

ЕКОНОМІЧНІ НАПРЯМИ МОДЕРНІЗАЦЇ̈ ДЕРЖАВНОЇ ФІНАНСОВОЇ ПОЛТТИКИ СТАЛОГО РОЗВИТКУ УКРАЇНИ

\author{
ДВНЗ "Університет банківської справи", \\ вул. Андріївська, 1, м.Київ, \\ 04070, Україна, \\ тел.: (044) 462-53-05 \\ e-mail: ubs@ubs.edu.ua
}

\begin{abstract}
Анотація. Стаття спрямована на виявлення економічних напрямів модернізації державної фінансової політики сталого розвитку України. Досліджено п'ять основних вимірів формування сталого розвитку: енергетична безпека, інтеграція внутрішнього енергетичного ринку, економічний союз, прогресивна політика для використання глобалізації, правосуддя та основні права громадян. Встановлено, що міграція покращує процес, що сприяє сталому розвитку. Міграційна політика повинна будуватися на солідарності та відповідальності та матиме додаткову перевагу - зробити цінний внесок у економічний розвиток і ефективність у довгостроковій перспективі. Виходячи із досліджень п’яти основних вимірів, що стимулює розвиток економіки сформовано основні напрями покращення державної фінансової політики сталого розвитку: покращення інвестиційного клімату, формування єдиного цифрового ринку, входження в структуру Європейського енергетичного союзу. Автором сформовано основні індикатори економічного напряму фінансової політики сталого розвитку: ВВП на душу населення; видобуток енергетичної сировини; видобуток неметалевих та будівельних матеріалів; видобуток рудної сировини; частка невідновлюваної енергії у валовому внутрішньому енергоспоживанні; внесок електроенергії, виробленої з відновлюваних джерел енергії; виробництво електроенергії джерелами та паливом; енергоємність економіки; кінцеве споживання палива та енергії в галузях економіки, а також електроенергії в галузях економіки; виробництво радіоактивних відходів; продуктивність вантажів; продуктивність пасажирських
\end{abstract}

